Review article

\title{
Epidemiological surveillance of infectious diseases in France
}

\author{
Barbara DufouR*, Sébastien LA VIEILLE \\ Agence Française de Sécurité Sanitaire des Aliments (AFSSA), \\ Direction de l'évaluation des risques nutritionnels et sanitaires, \\ 23 avenue du général de Gaulle, BP 19, 94701 Maisons-Alfort, France
}

(Received 19 February 1999; accepted 14 October 1999)

\begin{abstract}
Epidemiological surveillance, namely the continuous monitoring of diseases and health determinants in a population, has developed over the past fifteen years, in the sphere of human health as well as in animal health. All epidemiological surveillance networks include the following four stages: data collection, data transmission, data processing and dissemination of information. However, despite this basic similarity, the very many networks existing in France are extremely varied in nature. At the national level, the bodies involved in epidemiological surveillance for infectious animal diseases are the Direction générale de l'alimentation, the Agence française de sécurité sanitaire des aliments and, to a lesser degree, the Institut français de recherche pour l'exploitation de la mer. In the field, the networks rely on the Direction des services vétérinaires, veterinary practitioners, laboratories in each département, and livestock producers' groups (especially animal health protection groups). Some twenty French networks currently in operation are presented in this article according to a classification based on published criteria. In the case of human infectious diseases, epidemiological surveillance is carried out almost entirely by the Direction générale de la santé and the Directions départementales d'action sanitaire et sociale, the Institut de veille sanitaire and the various Centres nationaux de référence (CNRs). Most human infectious diseases are monitored by one or more of the following broad categories of networks: reporting of notifiable diseases, the CNRs, the network of sentinel doctors, the network of hospital laboratories and departments, and medical causes of death. An example where surveillance is covered by several networks is also presented, namely surveillance for salmonellosis and Salmonella. Lastly, methods for evaluating networks are discussed.
\end{abstract}

epidemiological surveillance / network / France / human / animal / infectious disease

Résumé - La surveillance épidémiologique des maladies infectieuses en France. La surveillance épidémiologique, qui correspond au suivi en continu des maladies et facteurs de santé dans une population, se développe depuis une quinzaine d'années, tant en santé humaine qu'en santé animale. Tous les réseaux de surveillance épidémiologique comportent les quatre étapes suivantes : récolte des données, transmission des données, traitement des données et

* Correspondence and reprints

Tel.: (33) 01497713 31; fax: (33) 01497713 36; e-mail: b.dufour@dg.afssa.fr 
diffusion de l'information; cependant la variété et le nombre des réseaux recensés en France sont importants. Les organismes français impliqués dans la surveillance épidémiologique des maladies infectieuses animales sont au plan national : la Direction générale de l'alimentation, l'Agence française de sécurité sanitaire des aliments et dans une moindre mesure, l'Institut français de recherche pour l'exploitation de la mer. Sur le terrain, les réseaux font appel aux Directions des Services vétérinaires, aux vétérinaires praticiens, aux laboratoires départementaux et aux groupements d'éleveurs (en particulier les groupements de défense sanitaire). Une vingtaine de réseaux français en activité sont présentés dans cet article en fonction d'une classification selon plusieurs critères. La surveillance épidémiologique des maladies infectieuses humaines est réalisée essentiellement par la Direction générale de la santé et les Directions départementales d'action sanitaire et sociale, l'Institut de veille sanitaire et les différents Centres nationaux de référence (CNR). La plupart des maladies infectieuses humaines sont suivies par un ou plusieurs des grands types de réseaux suivants : la déclaration obligatoire de certaines maladies transmissibles (DO), les CNR, le réseau de médecins sentinelles, le réseau de laboratoires ou de services hospitaliers, les causes médicales de décès. L'exemple d'une surveillance par plusieurs réseaux est également présenté ; il s'agit de celle des salmonelloses et des salmonelles. Enfin, les modalités d'évaluation des réseaux sont exposées.

surveillance épidémiologique / réseau français / maladie infectieuse / humain / animal

\section{Table of contents}

1. Introduction..... 170

2. Aims and operation of epidemiological surveillance networks .......................................... 171

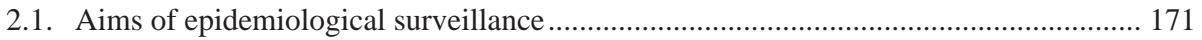

2.2. Main steps in the operation of surveillance networks ............................................... 171

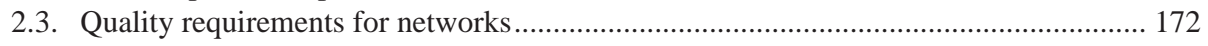

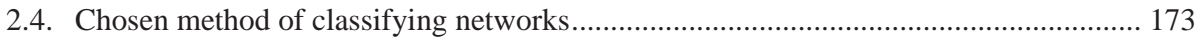

3. Animal epidemiological surveillance networks in France ...................................................... 173

3.1. Organisations involved in animal epidemiological surveillance in France..................... 173

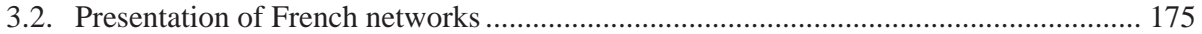

4. Human epidemiological surveillance networks in France ................................................... 175

4.1. Organisations involved in human epidemiological surveillance in France...................... 175

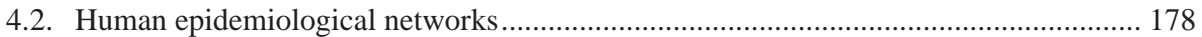

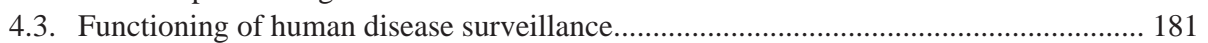

5. An example of epidemiological surveillance: Salmonella and salmonellosis ....................... 181

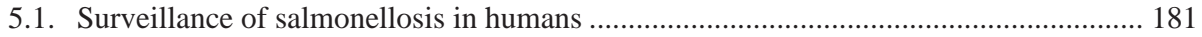

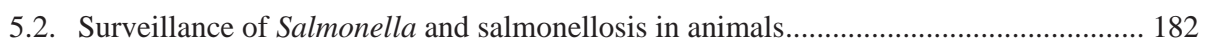

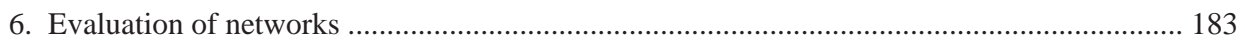

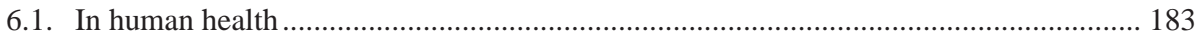

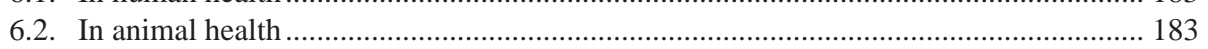

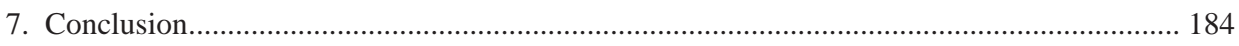

\section{INTRODUCTION}

The signing of the GATT (General Agreement on Tariffs and Trade) and the setting up of the World Trade Organization (WTO) have helped to develop international trade in animals and animal products on a global scale. To keep the sanitary risks associated with such trade to an acceptable level, sanitary rules have been set by the Office International des Epizooties (OIE) and the Codex Alimentarius Commission. In this new context, a precise and up-to-date knowledge of the epidemiological status of each of 
the major transmissible diseases is becoming increasingly necessary, if not obligatory. For a country to be in a position to place restrictions on international trade it must be able to provide scientific evidence (in other words based on reliable epidemiological data) of its status of freedom from the animal disease or diseases in question.

In addition to its importance for international markets, epidemiological surveillance is essential for the protection of animal populations from exotic or new diseases and for the implementation and evaluation of control programmes.

Lastly, the past few years have seen a considerable rise in consumer concerns over food safety, and the medical profession is keen to have advance warning of potential health problems. In this context, both human and animal epidemiological surveillance clearly have an increasingly important role.

Epidemiological surveillance has been defined as a system based on continuous information recording, making it possible to monitor the health status of a given population and the risk factors to which it is exposed, so as to detect pathological processes as they appear and study their development in time and space, with the objective of taking appropriate measures to control them [40].

\section{AIMS AND OPERATION OF EPIDEMIOLOGICAL SURVEILLANCE NETWORKS}

\subsection{Aims of epidemiological surveillance}

Epidemiological surveillance is a tool to assist decision making in matters of health. It is in fact through a better knowledge of the epidemiological status and its changes in time and space that the right health decisions can be taken.

The aims of epidemiological surveillance are as follows [41]:
- to detect a new or exotic disease when it occurs in a given geographical area, so as to instigate control measures as early as possible. Since surveillance for a disease that is not normally present in a given area requires slightly different methods, some authors have proposed the term 'epidemiovigilance' to designate this approach $[21,41]$;

- to enable the various diseases found in a given population to be ranked according to their importance in veterinary, economic or other terms, so as to be able to establish priorities for dealing with them. Local epidemiological surveillance networks such as VEGA [11] and VIALINE [27] or national networks such as RNOEA [19] have been set up with this aim;

- to evaluate the true extent of a disease (incidence, prevalence, economic losses, etc.) and monitor changes, so as to assist the decision-making process by indicating how it should be controlled or how an existing programme should be modified;

- to suggest lines of research.

\subsection{Main steps in the operation of surveillance networks}

Whatever the disease or health determinant being studied, epidemiological surveillance always includes the following steps $[21,38,41]$ :

1. Collection of data on the disease under surveillance, including a number of preliminary steps: the objectives must be precisely determined since they will determine the general way in which the network functions and the type and frequency of data to be collected and processed; in the case of a network operating on a sample of the population, care must be taken to ensure that the sample is representative, since this is vital for the accuracy of the results obtained; the type of data to be collected must then be determined and will depend largely on the 
disease in question; it is essential to standardise the data, so as to ensure that all the data collected will be comparable; lastly, data collection procedures (place, type of data, persons responsible for collection) must be strictly regulated.

2. Transmission of data to the central processing unit, which can be done in a simple and direct manner or may require a more complex procedure (active or passive form).

3. Data processing, which is inevitably followed by interpretation of the collated data, a task requiring close collaboration between epidemiologists and experts on the disease(s) in question.

4. Information distribution, which can be carried out by traditional means, such as regular bulletins or newsletters, or using more modern computerised or electronic transmission techniques. It must include internal distribution to all the members of the network, which is an effective way of keeping the various individuals involved motivated and is thus important for the smooth running of the network, and external distribution, for those not actively involved in the network but who could be involved in the subsequent control activities.

In addition to the methods used for epidemiological surveillance networks for diseases that are actually present in a given area, three further conditions are indispensable for the smooth running of epidemiovigilance networks for exotic animal diseases (diseases considered to be a threat but not actually present in the area under surveillance):

(a) A major awareness campaign for livestock farmers and veterinarians. Operating in the field, these persons are in regular contact with the animals, and are consequently in the best position to report the first clinical signs of a given disease. It is therefore essential for them to be fully aware of the presenting signs of the diseases for which surveillance is being set up. Regular cam- paigns must be carried out. The awareness campaigns for foot and mouth disease are an interesting case in point as they clearly illustrate the high level of investment in financial and human resources needed to achieve an adequate level of awareness among those in the field [32].

(b) One or more laboratories ready to carry out diagnostic tests for the disease in question. This may impose heavy infrastructure requirements (a secure laboratory when highly contagious diseases are involved) and the maintenance of competence levels, through contacts with international reference laboratories for example.

(c) A number of experts capable of providing scientific and technical support for those working in the field, and the essential task of analysing all suspected outbreaks reported in the field.

The considerable amount of resources needed to fulfil these conditions will almost certainly mean that a list of priorities has to be drawn up from among the exotic diseases requiring surveillance in the area in question.

\subsection{Quality requirements for networks}

Several authors $[2,38]$ have pointed out that for epidemiological surveillance networks to be effective they must possess the following qualities:

- sensitivity: the network must be capable of detecting and recording a maximum number of individuals affected by the disease in question;

- specificity: the network must detect only those individuals affected by the disease;

- representativity: when surveillance applies only to a sample of the population, the sample must be representative of the population: the sampling techniques employed in descriptive epidemiology (in particular, random sampling techniques) must therefore be used since they guarantee the accuracy of the result [10]; 
- strict conformity: in the field, the protocols for recording measurements or tests, as initially defined and standardised, must be strictly adhered to. The quality of the data collected must be regularly evaluated to ensure that consistency is being maintained in the field;

- rapidity: while this will vary according to the disease, data analysis and the resulting actions must be relatively fast and in keeping with the degree of urgency of the disease;

- regularity: the centralisation of data, and the processing and distribution of information, must be carried out in a regular manner so as to maintain the motivation of all those involved in the network;

- guaranteed future: an epidemiological surveillance network is normally set up for an indefinite period (in contrast to longitudinal studies). To guarantee their future, provision must to be made for regular funding and periodical awareness and training sessions for those working in the field.

\subsection{Chosen method of classifying networks}

Despite the great diversity of epidemiological surveillance networks, a method of classification has been proposed [24]. This classification scheme is based on the following criteria: the type of disease under surveillance (exotic disease or disease that is already present), the number of diseases covered (specific network or global network), the geographical area covered (regional, national or international network), the population covered (suspected cases or the susceptible population), the proportion of the population covered (based on a sample or the entire population), the method of forwarding the data to the central collection point (active or passive network) and the mode of operation (network integrated into an existing control programme or an autonomous network).
The main epidemiological surveillance networks in France will be presented according to this classification.

\section{ANIMAL EPIDEMIOLOGICAL SURVEILLANCE NETWORKS IN FRANCE}

\subsection{Organisations involved in animal epidemiological surveillance in France}

The national institutions most involved in epidemiological surveillance in France are:

- the Direction générale de l'alimentation (DGAl; Directorate general for food) including two subdirectorates specifically involved in epidemiological surveillance: the Sous-direction santé et protection animales (Sub-directorate for animal health and protection) and the Sous-direction hygiène alimentaire (Subdirectorate for food hygiene). These two sub-directorates are responsible for drawing up regulations and running the Veterinary Services. Their missions include epidemiological surveillance for exotic diseases (e.g. foot and mouth disease), certain zoonoses (bovine tuberculosis and brucellosis in various species of animal) and the major food contaminants (heavy metals, growth factors, antibiotic residues, etc.).

- The Agence française de sécurité sanitaire des aliments (AFSSA; French Food Safety Agency) is an administrative public body, placed under the joint supervision of the ministries responsible for health, agriculture and consumers, set up to evaluate risks relating to food and provide the necessary scientific and technical support for the development, application and evaluation of measures adopted by the public authorities in the following areas: animal health and protection, the quality of food products of 
animal origin, and veterinary drugs. To carry out these various duties, the AFSSA has a staff of around seven thousand, with a directorate general and thirteen specialised laboratories, each working in a different sector or on a different topic. The AFSSA brings together all the expert committees existing in its area of competence. Epidemiology has an important role in the work of the AFSSA. The Agency coordinates or participates in over a dozen epidemiological surveillance networks. To coordinate this epidemiological activity, a special department has been set up within the AFSSA directorate responsible for sanitary and nutritional risk evaluation.

- The Institut français de recherche pour l'exploitation de la mer (IFREMER; French fisheries research institute), an industrial and commercial public body with a staff of approximately 1250 , is involved in inshore environmental protection and, to this end, runs several surveillance networks.

The principal actors in the field are:

- The Directions des services vétérinaires (DSV, Veterinary services directorates) which organise, coordinate and manage regulatory animal disease control (exotic diseases or serious zoonoses); the control of foodstuffs of animal origin also falls within their remit as does gathering all the results of these activities. For a certain number of diseases and contaminants, DSV staff are therefore the principal actors in numerous epidemiological surveillance networks.

- Private veterinarians who are contacted to perform certain sanitary procedures (blood sampling to test for brucellosis, tuberculin testing, rabies vaccination of domestic animals, etc.) on behalf of the State. In France there are some 8000 veterinarians in private practice of whom 2300 practise partly or entirely in rural areas. These veterinarians are in close contact with livestock farmers. They can therefore play an important role in surveillance for a number of exotic diseases or in surveillance of diseases that are present in the country.

- The veterinary laboratories in each département (LVD) which, on behalf of the DSV, carry out the main tests required for regulatory control purposes (serological tests for brucellosis, enzootic bovine leukosis, Aujeszky's disease, etc.). At the request of livestock farmers and approved veterinarians, they carry out bacteriological, serological, virological and parasitological tests relating to the principal diseases of animals. They also conduct bacteriological and toxicological tests on foodstuffs of animal origin. These laboratories hold information that may be relevant to epidemiology and are therefore often associated with epidemiological surveillance networks.

- The Groupements de défense sanitaire $d u$ bétail (GDS; Cattle health protection associations). For over 30 years, livestock owners in France, assisted by the authorities, have formed health protection associations in the various départements, financed by the subscriptions of their members. Initially set up to try to convince farmers of the need to participate in local or national control programmes for the major infectious diseases (tuberculosis, foot and mouth disease, brucellosis), the GDS have gradually widened their scope to include other infectious diseases (paratuberculosis, bovine salmonellosis, etc.) or herd health problems (mastitis, neonatal diseases, etc.). They draw up joint control plans and coordinate and implement them with the support of veterinary laboratories in the various départements, veterinary practitioners, veterinary consultants, or technicians working with other bodies involved in livestock production. They also contribute to the identification of animals, an essential tool in any local or national control programme and any epidemiological surveillance activity. As a 
result of their work in coordinating a great many joint control activities, they hold a considerable amount of useful epidemiological information on the diseases concerned. They may therefore be able to play an important role in the epidemiological surveillance of a number of animal diseases.

\subsection{Presentation of French networks}

In 1992, at the request of the DGAl, a working group coordinated by the Centre national d'études vétérinaires et alimentaires (national centre for veterinary and food studies, now integrated into the AFSSA), made an inventory of, and studied, a majority of the animal epidemiological surveillance networks existing in France at that time [25].

The information on the various animal epidemiological surveillance networks presented here is largely derived from this work. However, as networks are dynamic and 'living' entities, some have ceased to exist since 1992 and new ones have been created. The information presented here on the new networks is derived from a study of the literature.

Tables I and II present the epidemiological surveillance and epidemiovigilance networks according to the classification system referred to above [24]. While the lists presented are not exhaustive, they nevertheless cover a majority of the animal epidemiological surveillance networks in operation in France in 1997.

In Tables I and II, there is a marked predominance of national (eighteen) compared to local (two) networks. However, it may well be that certain local networks did not come to light during the research.

Table III indicates the very wide range of animal species covered by the networks. Some networks (e.g. those for rabies and foot and mouth disease) involve several animal species.

\section{HUMAN EPIDEMIOLOGICAL SURVEILLANCE NETWORKS IN FRANCE}

\subsection{Organisations involved in human epidemiological surveillance in France}

At a national level, human epidemiological surveillance in France is carried out by three main types of institutions:

- The Direction générale de la santé (DGS; Directorate general for health) within the Ministry responsible for health, one of whose missions is "to monitor the appearance and the development of food-related diseases", and which is supported in the field by the Directions départementales d'action sanitaire et sociale (DDASS; Directorates for sanitary and social action in each département).

- The Centres nationaux de référence (CNRs; National reference centres) set up in 1972 by the Ministry responsible for health. These laboratories are responsible for identifying microbial strains isolated by medical laboratories in the field in cases where diagnosis is proven difficult, and in this way they participate in epidemiological surveillance and can raise the alarm in the event of epidemics.

- The Institut de veille sanitaire (InVS; National Institute for Health Surveillance), based on the Réseau national de santé public (RNSP; National public health network) was set up in 1999. The RNSP is a national administrative body supervised by the Secretary of State for Health. Its terms of reference include the coordination and development of epidemiological information, notably in the field of infectious diseases.

Numerous individuals and institutions operate in the field. These include general practitioners, hospitals, medical laboratories and the various DDASS. 


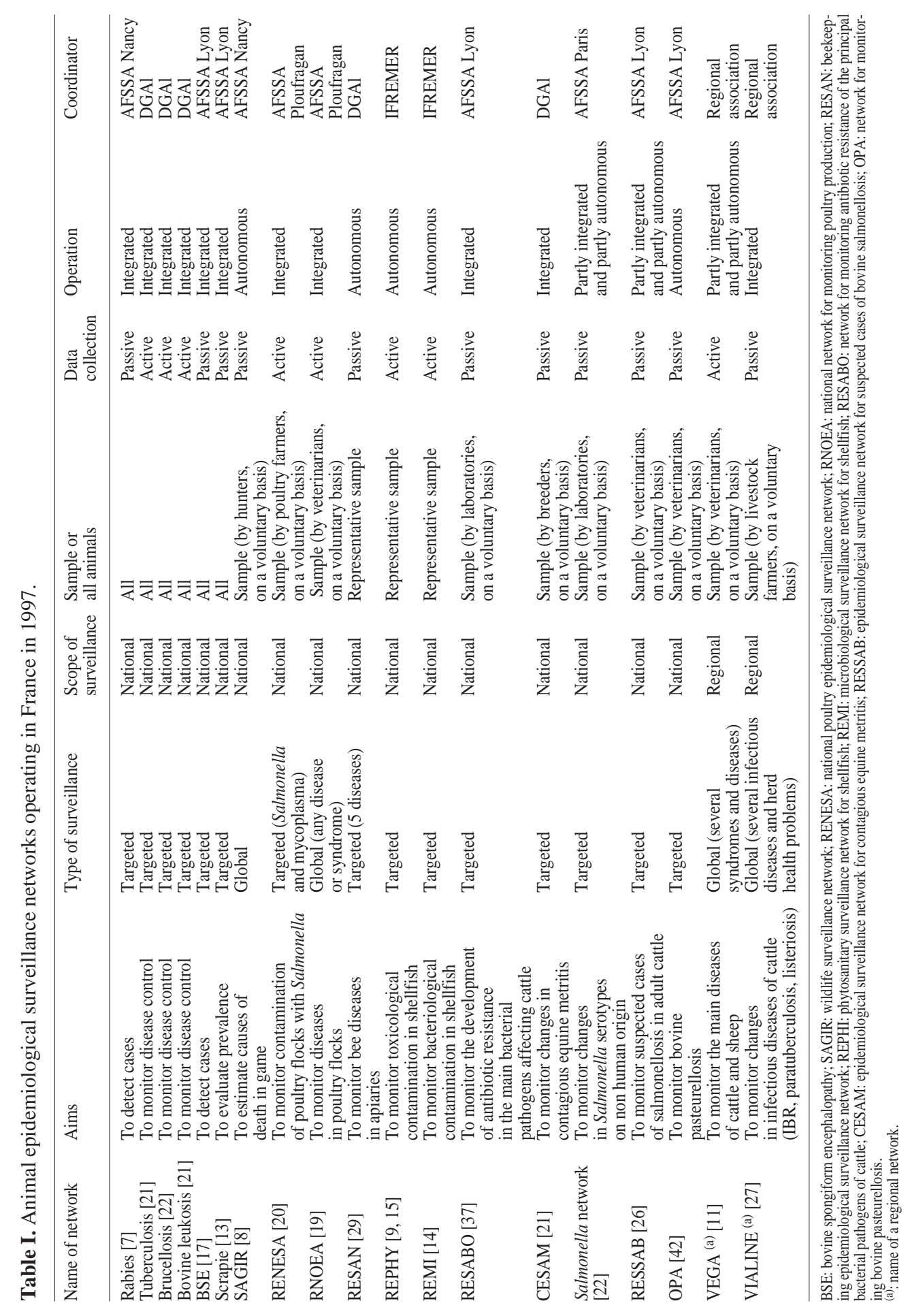




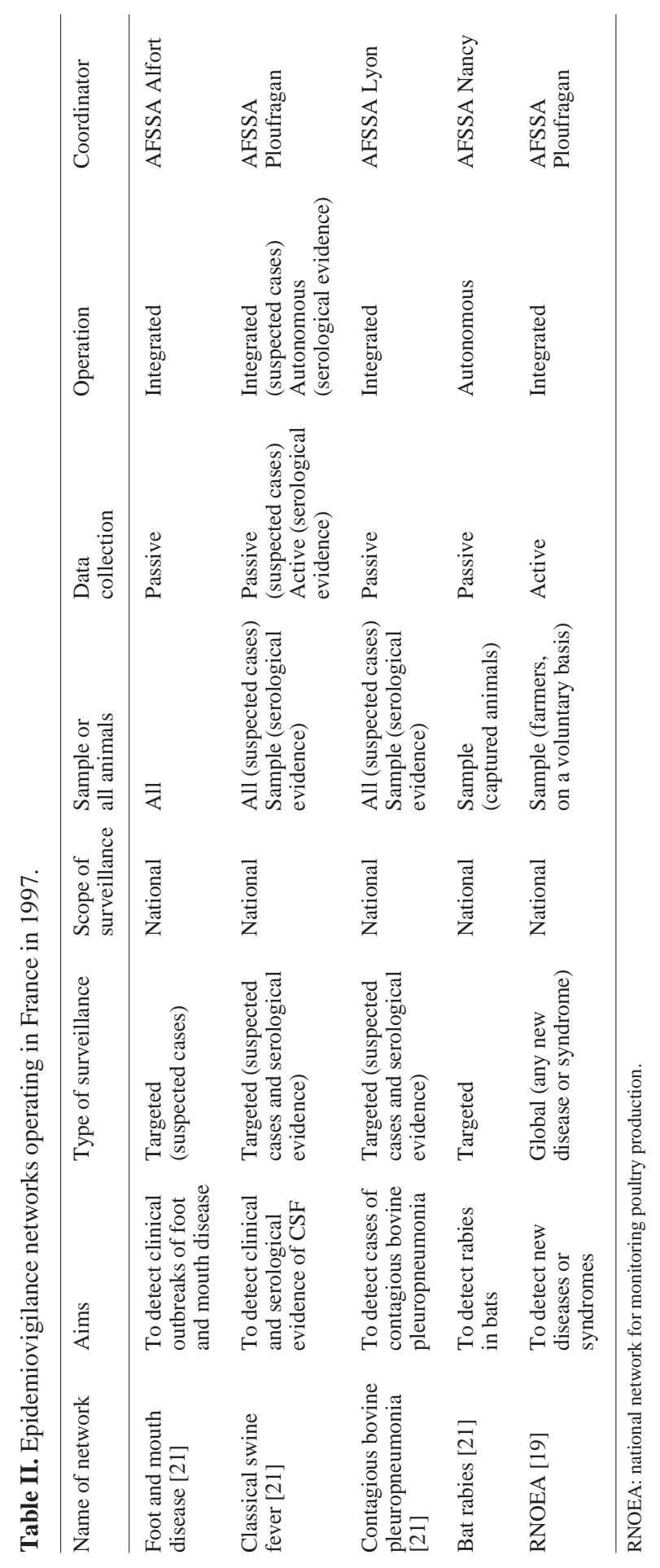


Table III. Animal species covered by epidemiological surveillance networks in France in 1997.

\begin{tabular}{|c|c|c|c|c|c|c|}
\hline \multicolumn{7}{|c|}{ Name of network } \\
\hline Cattle & Shellfish & Wildlife & $\begin{array}{l}\text { Small } \\
\text { ruminants }\end{array}$ & Pigs & Poultry & Others \\
\hline $\begin{array}{l}\text { FMD }^{(1)} \\
\text { CBPP }^{(2)} \\
\text { Rabies } \\
\text { Tuberculosis } \\
\text { Brucellosis } \\
\text { EBL }^{(3)} \\
\text { BSE }^{(4)} \\
\text { Vega }^{(5)} \\
\text { Vialine }^{(5)} \\
\text { RESSAB }^{(6)}\end{array}$ & $\begin{array}{l}\text { REMI }^{(7)} \\
\text { REPHI }^{(8)}\end{array}$ & $\begin{array}{l}\text { Rabies } \\
\text { SAGIR }^{(9)}\end{array}$ & $\begin{array}{l}\text { FMD }^{(1)} \\
\text { Rabies } \\
\text { Brucellosis } \\
\text { Scrapie }\end{array}$ & $\begin{array}{l}\mathrm{FMD}^{(1)} \\
\mathrm{CSF}^{(10)} \\
\text { Rabies }\end{array}$ & $\begin{array}{l}\operatorname{RENESA}^{(11)} \\
\text { RNOEA }^{(12)}\end{array}$ & $\begin{array}{l}\text { CESAM }^{(13)} \\
\text { (horses) }^{(14)} \\
\text { RESABO }^{(14)} \\
\text { Salmonella } \\
\text { bovine }\end{array}$ \\
\hline
\end{tabular}

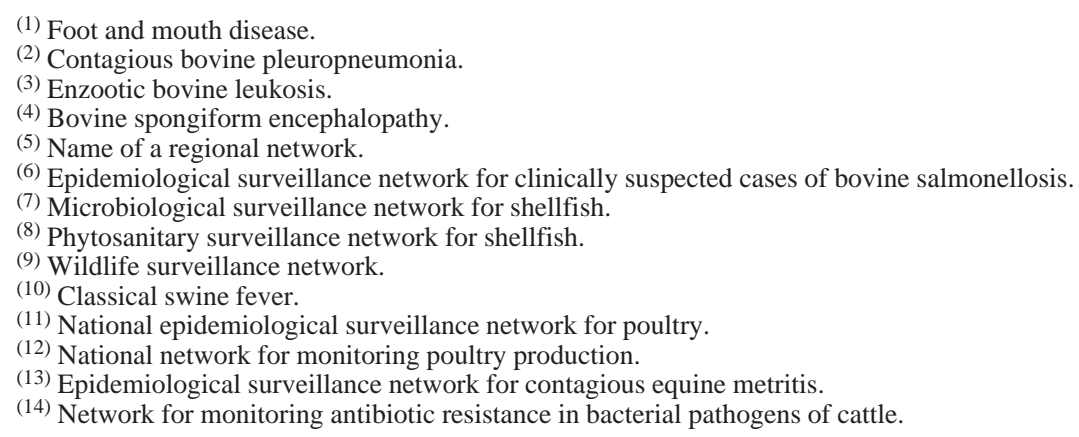

\subsection{Human epidemiological networks}

In France there are four main epidemiological surveillance systems for human infectious diseases:

- The notifiable disease surveillance network $[3,35]$. The list of notifiable diseases was established by ministerial decree on 10 June 1986. Of the twentyone infectious diseases covered by the notifiable disease surveillance network (column ND in Tab. IV), most are sufficiently serious to require hospitalisation. In such cases it is the hospital doctor who notifies the relevant DDASS after confirmation of the diagnosis. The index case for each disease has to be confirmed by the appropriate CNR. The DDASS verify that the various criteria for declaration have been met before submitting the weekly number of cases to the InVS, using specially designed forms. The collated information is regularly published in the Bulletin épidémiologique hebdomadaire (BEH; Weekly epidemiological bulletin). The surveillance system for notifiable diseases is thus a national network aimed at monitoring existing diseases and providing surveillance for exotic diseases (e.g. typhus and cholera). This system should, in principle, provide exhaustive coverage, with the information being collected and then centralised passively, based on a network integrated into the everyday diagnostic procedures conducted by the hospital or the general practitioner. However, as in the case of any passive surveillance system, the notifiable disease system does not result in all cases being recorded, and this 
Table IV. Human infectious diseases under surveillance in France in 1999 (B. Hubert, updated personal communication actualised by decree $n^{\circ} 99363$ the 6th May 1999).

\begin{tabular}{|c|c|c|c|c|c|}
\hline $\begin{array}{l}\text { Disease or agent } \\
\text { under surveillance }\end{array}$ & $\mathbf{N D}^{(1)}$ & $\begin{array}{l}\text { Medical } \\
\text { practitioner } \\
\text { networks }\end{array}$ & $\begin{array}{l}\text { Laboratory } \\
\text { networks }\end{array}$ & $\mathrm{CNR}^{(2)}$ & $\begin{array}{l}\text { Other information } \\
\text { sources }\end{array}$ \\
\hline Acute diarrhoea & & + & & & \\
\hline AIDS & + & & & + & \\
\hline Anaerobic bacteria & & & & + & \\
\hline \multicolumn{6}{|l|}{ Arbovirus infections } \\
\hline Dengue & & & & + & Local networks \\
\hline Yellow fever & + & & & + & \\
\hline Botulism & + & & & + & \\
\hline Brucellosis & + & & & & Veterinary surveillance \\
\hline Campylobacter & & & + & & \\
\hline Chickenpox & & + & & & \\
\hline Chlamydia & & & + & + & STD clinics \\
\hline Cholera & + & & & + & \\
\hline Creutzfeld-Jakob disease & + & & & & \\
\hline Diphtheria & + & & & & Survey on vaccination coverage \\
\hline Enterovirus & & & + & + & \\
\hline Exanthematic typhus & + & & & + & \\
\hline German measles & & & + & & Survey on vaccination coverage \\
\hline Gonococci & & & + & + & STD clinics \\
\hline Haemophilus & & & + & + & \\
\hline HIV infections & + & + & + & + & Surveys, blood donors \\
\hline Hydatidosis & & & & + & Occasional surveys \\
\hline HTLV infections & & & & & Blood donors \\
\hline Influenza - influenza syndrome & & + & & + & Drugs, days off work \\
\hline Legionnaire's disease & + & & & + & \\
\hline Leishmaniosis & & & & + & Occasional surveys \\
\hline Leptospirosis & & & & + & \\
\hline Listeriosis & + & & + & + & Veterinary surveillance \\
\hline Malaria & + & & & + & \\
\hline Male urethritis & & + & & & \\
\hline Mass food poisoning & + & & & + & Veterinary surveillance \\
\hline Measles & & + & + & & Survey on vaccination coverage \\
\hline Meningococcus & + & & + & + & \\
\hline Mumps & & + & + & & Survey on vaccination coverage \\
\hline \multicolumn{6}{|l|}{ Mycobacteria } \\
\hline Atypical M., leprosy & & & & + & \\
\hline Tuberculosis & + & & & + & Occasional surveys \\
\hline Mycosis & & & & + & \\
\hline Pasteurellosis & & & & + & \\
\hline Plague & + & & & + & \\
\hline Pneumococcus & & & + & + & \\
\hline Poliomyelitis & + & & + & + & Survey on vaccination coverage \\
\hline Rabies & + & & & + & Veterinary surveillance \\
\hline Rickettsiosis & & & & + & \\
\hline Salmonella typhi et paratyphi & + & & & + & Veterinary surveillance \\
\hline Shigella & & & & + & \\
\hline Staphylococci & & & & + & \\
\hline Streptococci & & & + & & \\
\hline Syphilis & & & + & + & STD clinics \\
\hline T. Shock syndrome & & & & + & \\
\hline Tetanus & + & & & & \\
\hline Toxoplasmosis & & & & & Occasional surveys \\
\hline Tularaemia & & & & + & \\
\hline Viral haemorrhagic fever & + & & & + & \\
\hline Viral hepatitis & $+(\mathrm{B})$ & + & & + & Local networks \\
\hline Whooping cough & & & + & & Survey on vaccination coverage \\
\hline Yersinia & & & & + & \\
\hline
\end{tabular}

(1) Notifiable disease; ${ }^{(2)}$ national reference centre; STD: sexually transmitted disease. 
arrangement must therefore be complemented by other means of surveillance (Tab. IV).

- The CNR networks. There are currently 38 CNRs, 18 of which are located at the Pasteur Institute in Paris. The epidemiological surveillance conducted by the CNRs is based on a voluntary system whereby laboratories send them the strains they have isolated. These networks are therefore not exhaustive. Data collection is passive and the networks are integrated, being based on the everyday diagnoses carried out by the laboratories.

- Networks of sentinel doctors. The Réseau national télématique sur les maladies transmissibles (RNTMT; National computerized network for transmissible diseases) was set up in 1984 as a result of collaboration between INSERM and the DGS [16, 28, 31, 35]. This network is based on the daily recording by some 500 sentinel doctors, representing approximately $1 \%$ of general practitioners in France (of the 137000 doctors practising in France, just over 60000 are general practitioners), of eight transmissible diseases (measles, mumps, chickenpox, influenza-like syndromes, acute diarrhoea, viral hepatitis, male urethritis, and prescriptions for HIV serology in general medicine) observed in private practice. Sentinel doctors are unpaid volunteers and were selected to try to ensure a representative sample. Sentinel doctors communicate electronically with the INSERM unit (U 444) acting as coordinating centre. The RNTMT is therefore a national epidemiological surveillance network, based on a sample that is intended to be representative of French doctors. Data communication is passive, but active reminders are automatically generated in the event of data not having been submitted. Lastly, the network is integrated, being based on the routine work of general practitioners.

- Networks of public (hospital laboratories) or private laboratories (laboratoires d'analyses biologiques et médicales). In the 1980s, the national health laboratory (epidemiology unit) set up a group of general or specialist networks of public or private medical laboratories. The general network: EPIBAC (bacterial epidemiology) created in 1983, includes hospital laboratories from all over France [39]. It covers approximately $63 \%$ of hospital laboratories in Metropolitan France and records systemic infections caused by Haemophilus influenzae, Neisseria meningitidis, Streptococcus pneumoniae, Streptococcus groups A and B, and Listeria monocytogenes. The specialist networks, comprising public or private laboratories throughout France, cover specific disease agents identified by isolation or serology. They include RENACHLA (Chlamydia), RENAGO (gonococci), RENAVI (HIV), RENARUB (German measles), RENACOQ (whooping cough) and the surveillance network for haemolytic and uraemic syndromes (SHU). As the National Health Laboratory no longer exists, the various laboratory networks are now coordinated by the InVS [35]. All these laboratories provided a comprehensive monthly report on all that has been isolated or identified during the period, either as a result of routine sampling or in response to clinical syndromes. These networks are therefore epidemiological surveillance networks: participation of the laboratories is voluntary, the procedure for communicating these data is passive, and these networks are integrated into the routine diagnostic procedures carried out by the laboratories.

- National statistics on causes of death. Since 1968, INSERM (National institute for health and medical research) has been responsible for preparing annual national statistics on causes of death in association with INSEE (National institute for statistics and economic studies). The relevant information is sent to INSERM by each DDASS on the basis of a death 
certificate and a bulletin on causes of death. Death certificates are in two parts: the first part is used for the official declaration of death, and the second part, which is anonymous, includes the cause of death and any associated morbid or psychological conditions. The death bulletin (written by a registry officer) is based on the contents of death certificates and provides details of civil status and socio-demographic characteristics (anonymous data). This system is therefore integrated into national epidemiological surveillance on the basis of annual statistics on mortality [1].

- There are also groups of networks that do not necessarily provide national coverage but through the application of certain operating rules allow the data collected by each of the networks to be shared. A typical example of this type of system is the Observatoire national de l'épidémiologie de la résistance bactérienne aux antibiotiques (ONERBA; National centre for monitoring bacterial resistance to antibiotics), an association of 11 laboratory networks and three CNRs. In a similar manner, 'RESOR VIH' coordinates the surveillance conducted by 11 Observatoires régionaux de la santé (ORS; Regional health observatories) on screening for HIV infection [12].

\subsection{Functioning of human disease surveillance}

All the human epidemiological surveillance networks are passive. The data collected in the field are thus forwarded spontaneously, and the success of the network tends to depend on the extent to which those working in the field have been made aware of the importance of the network. It has been shown [35] that the level of reporting is highly variable from one disease to another. Thus in the case of poliomyelitis, the reporting rate is considered to be $100 \%$, for AIDS $85 \%$ and for tuberculosis only $50 \%$. Furthermore, the rate is highly variable from one département to another (ranging from 0 to $100 \%$ ). There are various reasons for under-reporting. InVS staff have found that the level of disease reporting generally tends to be lower for less serious diseases $[30,35]$. For example, in the event of mass food poisoning, only $20 \%$ of cases of notifiable diseases are thought to be reported to the notifiable disease network and around $50 \%$ of cases to the CNRs, whereas listeriosis is more frequently reported. To compensate for this under-reporting, most of the major infectious diseases are covered by several networks, as shown in Table IV. On the one hand this method allows a greater number of cases to be recorded, and on the other hand it means that the rate of under-reporting can be estimated, using capture-recapture methods [4].

\section{AN EXAMPLE \\ OF EPIDEMIOLOGICAL SURVEILLANCE: SALMONELLA AND SALMONELLOSIS}

Certain zoonoses, for which the disease agent is ubiquitous, are covered by several animal and human surveillance networks. Salmonella and salmonellosis provide an interesting example of the need for complementarity between different surveillance systems.

\subsection{Surveillance of salmonellosis in humans}

The surveillance of salmonellosis in humans is carried out in part by the CNRs and also through the compulsory reporting of any mass food poisoning incident.

- The CNR acts upon all requests for serotyping Salmonella strains received from biological and medical laboratories, which submit the strains they have isolated on a voluntary basis. The CNR maintains a file on each strain that it receives, including the date of isolation, the town of origin, the age-group of the patient, the type of sample taken, and the assumed 
source of contamination [30]. When, during a given period, the number of strains corresponding to a particular serotype shows an increase of more than $20 \%$ in respect to the same period the year before, this triggers an alert which may lead to an investigation by the InVS [5].

- Any mass food poisoning incident (occurrence of at least two cases of a disease, usually digestive, which can be traced back to a common food source) must be reported to the health authorities of the département where it occurred (DDASS or DSV) [33]. However, mass food poisoning incidents are not restricted to Salmonella. Since the setting up of the surveillance system, Salmonella have represented $60 \%$ to $70 \%$ of such incidents where the cause could be identified. In principal, as soon as a report is received two investigations are conducted in parallel, one by the DDASS to look into the medical aspects (number of cases, gravity, and possibly a case-control study to determine the likely source of contamination), and the other by the DSV to try to trace the source of the epidemic and the contributory factors (non compliance with rules of hygiene, etc.). The results of the DDASS investigation are sent to the InVS and those of the DSV investigation to the DGAl. Under an agreement between the Ministries responsible for agriculture and health the two files are collated for use by the InVS.

\subsection{Surveillance of Salmonella and salmonellosis in animals}

Given the ubiquitous nature of Salmonella, surveillance of Salmonella that are non human in origin is also covered by several networks: a general network, the "Salmonella" network, and several specific networks aimed at monitoring the situation in the various types of animal production.

- The "Salmonella" network, coordinated by AFSSA Paris, provides surveillance of Salmonella serotypes of animal origin (food product, animal pathology or natural ecosystem), determining their relative importance and monitoring changes over time. Public and private laboratories receive samples, either for diagnostic purposes or within the context of control programmes, to test for Salmonella. In some cases, they carry out their own serotyping of strains, but when they do not have access to the necessary sera, they send the strain to AFSSA Paris, which carries out the typing on their behalf.

There are currently nearly 200 public and private laboratories that send strains or information to AFSSA Paris. These data are processed and a comprehensive report is sent each month to the CNR for Salmonella. Of the 21500 strains dealt with annually by the "Salmonella" network, some 13000 are derived from "animal health", the remainder relate to analyses conducted on food products or in natural ecosystems. Thanks to this network, the overall evolutionary trends of the various serovars and the origin of strains can be determined and monitored over time.

- The Réseau national d'épidémiosurveillance en aviculture (RENESA; National epidemiological surveillance network for poultry production), run by AFSSA Ploufragan, provides surveillance for contamination of poultry flocks and hatcheries subject to official hygiene and sanitary controls and in which samples are frequently taken to test for the presence of Salmonella.

- The recently set up Réseau d'épidémiosurveillance des suspicions cliniques de salmonelloses bovines (RESSAB; Epidemiological surveillance network for suspected cases of bovine salmonellosis), run by AFSSA Lyon, is a pilot scheme providing surveillance for the disease in cattle herds in 14 départements.

- RESABO, aimed at monitoring the development of antibiotic resistance in the 
principal bacterial pathogens of cattle, centralises and analyses the results of tests to establish antibiotic sensitivity profiles carried out in département laboratories.

- Lastly, the Veterinary Services, under the control of DGAl, implement surveillance plans for food raw materials (milk, meat) to check that they are not contaminated. Furthermore, the DSV play a very active role in the surveillance system for mass food poisoning.

Data relating to the epidemiological surveillance networks for human salmonellosis are centralised at the InVS, and include data on food poisoning originating from the DSV. The epidemiological surveillance networks for animal salmonellosis are all coordinated by AFSSA. Meetings and information sharing take place on a regular basis between the different actors involved in all these networks.

\section{EVALUATION OF NETWORKS}

The quality of the epidemiological information produced by a surveillance network is highly dependent on the functional quality of the network. The evaluation of such networks is therefore a necessary procedure in order to determine the reliability of the results obtained. Yet very few studies have been published to date on the application of evaluation methods to epidemiological surveillance.

\subsection{In human health}

Qualitative approaches have been proposed. Some of these were aimed at describing the characteristics of an effective epidemiological surveillance network $[2,18]$; another consisted of examining the extent to which existing surveillance systems in France were relevant and appropriate to needs [34].

Furthermore, capture-recapture methods, allowing an evaluation to be made of the exhaustiveness of the results achieved by surveillance systems, are commonly used in human health to evaluate the sensitivity of surveillance systems [30].

\subsection{In animal health}

A survey on methods of epidemiological surveillance for transmissible animal diseases was conducted by a working group at the Office International des Epizooties. The aim was to gather information on the state of information systems in different countries and make a qualitative assessment, with a view to proposing improvements. The situation existing in 34 countries was thus analysed [6]. Nevertheless, the relentless growth of international trade and the development of such concepts as regionalisation and risk analysis means that a quantitative analysis of animal health surveillance systems is now required. This is no doubt the reason why different approaches at quantitative analysis in animal epidemiological surveillance have already been attempted [23, 36].

The first approach [36] was to attempt a global analysis of epidemiological surveillance within a country. The author pointed out that any evaluation of epidemiological surveillance networks must inevitably begin with a list and a description of all the methods of surveillance existing in the country. An assessment grid was then proposed. The grid comprises four parts: disease agent surveillance, host monitoring, environmental assessment, and the epidemiological delivery system itself. These four parts are each subdivided into a number of specific aspects. The country is scored on a scale of 0 to 4 depending on the capabilities that it possesses on each of the specific aspects of surveillance. A score of 0 indicates a country that has no surveillance system in place; 1 corresponds to minimal basic systems, and a score of 4 corresponds to complete systems, in which each section functions perfectly. This method is concerned with the capacity of a country to carry out general 
epidemiological surveillance of animal diseases rather than with the functioning of individual networks.

The second approach [23] is based on a proposed technical and economic method for the quantitative evaluation of the operating quality of epidemiological surveillance networks, with a view to their improvement. This tool proposes an evaluation grid of the main critical points in the operation of epidemiological surveillance networks and a guide for scoring each critical point. The overall evaluation results in a score out of one hundred, and leads to proposals for improvements on the critical points that were least successfully managed. The suggestion was also made to calculate the annual operating cost of the network and the cost of improvements, and to relate these costs to the gain in quality if the suggested improvements were implemented. These figures provide a basis for determining which improvements (i.e. the most cost effective) should be given priority.

\section{CONCLUSION}

Despite the diversity and number of diseases under surveillance in France, both by human and animal epidemiological surveillance networks, the organisation of this surveillance is relatively straightforward and is based on several highly specialised national coordinators.

France has thus gained considerable experience in the field of epidemiological surveillance. The interconnection between different networks and the exchange of information between the coordinators of the main networks provides the decision makers with the relevant information on the existing epidemiological situation and its evolution.

Epidemiological surveillance networks are dynamic entities and are inevitably required to evolve. It is therefore advisable to continue to develop methods allowing regular evaluations of these networks to be carried out, so as to ensure that, over time, each of them can continue to fulfil the aims assigned to it.

\section{REFERENCES}

[1] Allouche P., Bellon O., Cavallo J.D., Chardon E., La résistance aux antibiotiques en France : bilan 1997 de l'observatoire national de l'épidémiologie et de la résistance bactérienne aux antibiotiques, Bulletin Epidémiologique Annuel 2 (1999) 179-182.

[2] Anonymous, Guideline for evaluating surveillance systems, Morbidity and Mortality Weekly Report, 37, NS-5 (1988) 18 p.

[3] Anonymous, Maladies à déclaration obligatoire en 1994, Bulletin Epidémiologique Hebdomadaire 40 (1995) 177-180.

[4] Anonymous, International working group for disease monitoring and forecasting. Capture-recapture and multiple-record systems estimation. I: History and theorical development, Am. J. Epidemiol. 142 (1995) 1047-1058.

[5] Anonymous, La surveillance des maladies transmissibles en France. Brochure éditée par le RNSP, la DGS et l'Institut Pasteur de Paris à l'occasion du $1^{\mathrm{er}}$ congrès de la surveillance des maladies transmissibles, 5 et 6 février 1996, La Villette, Paris.

[6] Anwar H., Systèmes de collecte des informations zoo-sanitaires et gestion des sources d'information. $61^{\mathrm{e}}$ session générale de l'Office international des épizooties, mai 1993, 18 p.

[7] Aubert M., Informatisation d'un laboratoire de diagnostic épidémiologique; étude d'un cas : le centre national d'étude sur la rage et la pathologie des animaux sauvages, Epidémiol. Santé Anim. 8 (1985) 51-66.

[8] Barrat J., Eichenlaud C., Artois M., Lamarque F., Le réseau SAGIR de surveillance de l'état sanitaire de la faune sauvage en France, Epidémiol. Santé Anim. 27 (1995) 93-104.

[9] Belin C., REPHY : le réseau de surveillance du phytoplancton, Epidémiol. Santé Anim. 28 (1995) 81-90.

[10] Bénet J.J., Sanaa M., Dufour B., Toma B., Méthodologie des enquêtes en épidémiologie animale, Rev. Elev. Méd. Vét. Pays Trop. 46 (1993) 403-422.

[11] Bichet H., Le réseau VEGA, Epidémiol. Santé Anim. 27 (1995) 11-29.

[12] Brice L., Infections à VIH : RESORS-VIH, Bulletin Epidémiologique Annuel 2 (1999) 27-29.

[13] Calavas D., Ducrot C., Coton T., Baron T., Belli P., Savey M., Surveillance scheme for scrapie in France, Epidémiol. Santé Anim. 31-32 (1997) 07.18.1-07.18.2. 
[14] Catherine M., Le réseau microbiologique REMI, Epidémiol. Santé Anim. 27 (1995) 81-91.

[15] Catherine M., Raffin B., La surveillance microbiologique et le classement des zones de production de coquillages du littoral Français, Epidémiol. Santé Anim. 29 (1996) 99-106.

[16] Chauvin P., Diaz C., Garnerin Ph., Guiguet M., Massari V., Saidi Y., Toubiana L., Valleron A.J., Réseau national télé informatique de surveillance et d'information sur les maladies transmissibles (R.N.T.M.T.) : présentation et architecture du réseau, Bulletin Epidémiologique Hebdomadaire 21 (1993) 97.

[17] Coudert M., Belli P., Savey M., Martel J.L., Le réseau national d'épidémiosurveillance de l'encéphalopathie spongiforme bovine, Epidémiol. Santé Anim. 27 (1995) 59-67.

[18] Declich S., Carter A.O., Public health surveillance : historical origins, methods and evaluation, Bulletin of the World Health Organization 72 (1994) 285-304

[19] Drouin P., Toux J.Y., Guittet M., Bennejean G., Le réseau national d'observations épidémiologiques en aviculture : RNOEA, Epidémiol. Santé Anim. 27 (1995) 45-58.

[20] Drouin P., Toux J.Y., Guittet M., Bennejean G., Le réseau national d'épidémiosurveillance en aviculture : RENESA, Epidémiol. Santé Anim. 28 (1995) 65-79.

[21] Dufour B., Les réseaux français d'épidémiosurveillance animale, Epidémiol. Santé Anim. 27 (1995) 1-10.

[22] Dufour B., Les réseaux français d'épidémiosurveillance animale et la protection de la santé publique, Epidémiol. Santé Anim. 28 (1996) 9-17.

[23] Dufour B., Technical and economic evaluation method for use in improving infectious animal disease surveillance networks, Vet. Res. 30 (1999) 27-37.

[24] Dufour B., Audigé L., A proposed classification of veterinary epidemiosurveillance networks, Rev. Sci. Tech. Off. Int. Epizoot. 16 (1998) 746758.

[25] Dufour B., Aubert M., Bastien J., Coche B., Coton T., Demol M., Dion F., Filleton R., Garnerin Ph., Lemasson B., Merlin P., Moutou F., Toma B., Touratier A., Vannier Ph., Les réseaux d'épidémiosurveillance animale en France : rapport du sous groupe de travail « recensement et analyse », DGAl CNEVA., octobre 1992, $22 \mathrm{p}$.

[26] Dufour B, Martel J.L., Coudert M., Desjouis G., Mise en place d'un réseau d'épidémiosurveillance des suspicions cliniques de salmonelloses bovines : RESSAB, Bull. Group. Tech. Vét. 551 (1997) 91-95.

[27] Durand F., Le réseau VIALINE, Epidémiol. Santé Anim. 27 (1995) 31-43.

[28] Flahault A., Garnerin Ph., Chauvin P., Carrat F., Massari V., Farrant N., Diaz C., Desenclos J.C.,
Lepoutre A., Valleron A.J., Epidémiologie des maladies transmissibles en médecine générale : bilan du réseau « sentinelle » en 1994, Bulletin Epidémiologique Hebomadaire 20 (1995) 87-91.

[29] Fléché C., Faucon J.P., Le réseau national d'épidémiosurveillance apicole : RESAN, Epidémiol. Santé Anim. 27 (1995) 69-79.

[30] Gallay A., Estimation du nombre de toxi-infections alimentaires collectives à Salmonella, Rapport réalisé au Réseau National de Santé publique, Saint Maurice, Janvier 1998, 47 p.

[31] Garnerin Ph., Valleron A.J., The French communicable diseases computer network: a technical view, Comput. Biol. Med. 22 (1992) 189-200.

[32] Gourreau J.M., Durand B., Moutou F., Dufour B., Savey M., Les mesures de lutte contre la fièvre aphteuse en France, Bull. Acad. Vét. Fr. 70 (1997) 213-218.

[33] Haeghebaert S., Le Querrec F., Vaillant V., Delarocque-Astagneau E., Bouvet P., Les toxiinfections alimentaires collectives en France en 1997, Bulletin Epidémiologique Hebomadaire 41 (1998) 177-181.

[34] Hubert B., Haury B., Orientations pour la révision des modalités de surveillance des maladies transmissibles en France, Bulletin Epidémiologique Hebdomadaire 26 (1996) 115-117.

[35] Hubert B., Laporte A., Lepoutre C., Roure C., Brunet J.B., Goulet V., Rebière I., Garnerin Ph., Valleron A.J., La surveillance des maladies transmissibles en France, Bulletin Epidémiologique Hebdomadaire 36 (1991) 166-167.

[36] Hueston W.D., Assessment of national systems for the surveillance and monitoring of animal health, Rev. Sci. Tech. Off. Int. Epizoot. 12 (1993) 1187-1196.

[37] Martel J.L., Epidémiosurveillance de l'antibiorésistance des bactéries pathogènes chez l'animal, Epidémiol. Santé Anim. 29 (1996) 107-120.

[38] Morris R., Information systems for animal health: objectives and components, Rev. Sci. Tech. Off. Int. Epizoot. 10 (1991) 13-23.

[39] Sarriot E., Le Vu B., Dednaoui P., Goulet V., Surveillance de la syphilis par l'intermédiaire des laboratoires d'analyse médicale, Bulletin Epidémiologique Hebdomadaire 30 (1994) 131-134.

[40] Toma B., Benet J.J., Dufour B., Eloit M., Moutou F., Sanaa M., Glossaire d'épidémiologie animale, Le point vétérinaire ed., Maisons-Alfort, 1991, $365 \mathrm{p}$.

[41] Toma B., Dufour B., Sanaa M., Bénet J.J., Ellis P., Moutou F., Louza A., Epidémiologie appliquée à la lutte collective contre les maladies transmissibles majeures, Association pour l'étude de l'épidémiologie des maladies animales, MaisonsAlfort, France, 1996, 551 p.

[42] Vandaele E., Schering-Plough et le CNEVA Lyon : les pasteurelles sous surveillance, La Semaine Vétérinaire 790 (1995) 36. 